If, he has not yet published it I hope he will do so, as the point is of importance. Of course, such a stool may contain some colourless decomposition product of bile pigment, but that is not suggested in the passage I have quoted. The question is one of colour.-I am, Sirs, yours faithfully,

Exeter, Dec. 15th, 1905 W. GORDON.

\section{THE PROPOSED AMALGAMATION OF THE LONDON MEDICAL SOCIETIES.}

To the Editors of THE LANCET.

SIRS, - In the proposed scheme as adopted at the meeting of the general committee of representatives of the societies held on July 19th it is suggested that "every member of the societies which amalgamate shall have the option of joining the new society, subject to the rules of the said society, without entrance fee, and that as far as possible members of these societies shall retain their present privileges in the new society." This is quite satisfactory, lut the paragraph then goes on to say: "For example, any Fellow of the Royal Medical and Chirurgical Society who has compounded for his subscription will be entitled to join the Royal Society of Medicine as a Fellow without further payment of any kind, and a member of any society who has compounded for his subscription will be entitled to join the corresponding section of the Royal Society of Medicine without further payment." Presuming that the Medical Society of London were willing to join the scheme under this arrangement, of what section would its Fellows be members? The Medical Society of London deals with all branches of medical science and consequently its Fellows being made members of one or more sections would not give them their present advantages.

In paragraph numbered 2 of the proposed scheme it says that "all monies, books, premises, and other properties belonging to any of the societies which join the proposed union shall become the property of the new society," and the Royal Medical and Chirurgical Society proposes that the following words should be added " and shall be vested in the Fellows." The result of this arrangement would be that the real and personal property of the present Medical Society of London would be transferred absolutely to those Fellows of the Royal Medical and Chirurgical Society who had com. pounded for their subscriptions; and the Fellows of the Medical Society, as they would only become members of a section of the Royal Society of Medicine, would lose all interest in, and control over, the ir present property. The Royal Medical and Chirurgical Society proposes for paragraph numbered 4 that "the Fellons of the society shall meet annually for the election of officers and other business, \&c., \&c." Paragraph numbered 7 states that "the Fellowshjp of the society shall be restricted to men who are registered medical practitioners of the Briti:h empire and to men whose scientific attainments are sutisfactory to the general council." Paragraph numbered 9 says that "each section shall have the power to elect as members of the society such persons as the council of the section may think fit, provided that the names of the candidates proposed for election be prev:ously submitted," and the Royal Medical and Chirurgical Society proposes the addition of the words " to the council of the society and approved by them." Paragraph numbered 11 says that "the general management of the society shill be under the control of a general council, consisting of the president, the presidents of the varions sections, two treasurers, two librarians, two secretaries. and eight other Fellons." The Rojal Medical and Chirurgical Society proposes adding to this, "the members of council, with the exception of the presidents of the sections (who are to be ex officio members) shall be elected by the Fellon's."

It will be seen from the above quotations that all power is to be placed in the hands of the Fellows of the new society. From the first paragraph quoted it will be seen that at the commencement of the new society the only Fellons will be those Fellows of the Royal Medical and Chirurgical Scciety who have compounded for their subscription and they will have absolute power over everything, as shown by the above quotations. Is it, to be expected that other societies are going to entirely give up their rights in this way? Why should not the Fellows and members of other societies who have compounded for their subscription be entitled to join the Royal Society of Medicine as Fellons instead of as members of a section? Such a scheme as proposed seems to me doomed to failure, as disappointment and dissatisfaction would be sure to follow, with the result that other societies would be formed and consequently the Fellows and members of the Royal Society would dwindle in number until it would be unable to meet its financial liabilities.

I am, Sirs, yours faithfully,

Wimpole-street, W., Dec. 18th, $1905 . \quad$ Geo. STEELE-PERKINs.

PS.-The italics are mine.-G. S.-P.

\section{THE PARLIAMENTARY REPRESENTATION OF THE UNIVERSITIES OF EDINBURGH AND ST. ANDREWS.}

\section{To the Editors of THE LANCET.}

SrRs,-I am credibly informed that certain canvassers who are endeavouring to gain support for my opponent, $\mathrm{Mr}$. St. Loe Strachey, are making statements regarding $\mathrm{my}$ action in the General Medical Council which are the reverse of accurate. Generally, it has been stated that I either absent myself from the Council when penal cases are under consideration or do not vote, especially that I left the Council-room when the Rusholme case was being deliberated on during the late session. As to the general statement, I may say that I have sat for 18 years as member of the Council and that I have never been absent a single day during 35 sessions and that I have taken part in every penal case, except, perbaps, on one or two occasions when I was obliged to be in the House of Commons. As to the particular statement, I plead that when the Rusholme case was before the Council I and Mr. Jackson obtained leave from the President to be absent for an hour and a half in order to attend a deputation consisting of members of the British Medical Association and other societies at the Local Government Board Office and that I introduced the members of the deputation to $\mathbf{M r}$. Gerald Balfour. The object of the interview was to promote the interests of medical men working under the Local Government Board. These statem nts will, I am sure, be endorsed by every member of the Council. As the deliberation s on penal cases take place in camerâ, the misleading statement must have arisen from some vague and unsubstantial rumour.

I am, Sirs, yours faithfully, John BatTy TUKE.

Charlotte-square, Edinburgh, Dee. 18th, 1905.

\section{THE FREEZING POINT OF THE BLOOD. To the Editors of THe LaNCET.}

SIRS, - In The LANCET of Dec. 16th, p. 1772, there is a report of a discussion at the Medical Society of London on Modern Methods of Diagnosis in Kidney Disease, in which Mr. E. Hurry Fenwick is represented as saying: " The normal free zing point of the blood was $-0.60^{\circ} \mathrm{C}$. and this was lowered in pathological conditions to $-059^{\circ}$ or $-0.57^{\circ}$." This is about the most novel form of lowering I have come across for some time, and if such a palk able error had come from the Sister Isle it would probably have been described as an Iriskman's rise. As a matter of fact, the normal freezing point of the blood ranges from $-0.55^{\circ}$ to $-0.57^{\circ} \mathrm{C}$, and in some pathological conditions it may fall even below $-0.60^{\circ} \mathrm{C}$

Liverpool, Dec. 20th, 1905.

JAMES BARR.

** We regret that the slip should have been overlooked in the proof.-ED. L.

\section{DEATH OF A DIVER FROM AIR EMBOLISM. \\ To the Editors of THE LANCET.}

SIRs, - The diver in question ${ }^{1}$ died because his body fluids had dissolved air at the pressure at which he worked. Thi: air effervesced off in his blood-vessels owing to his rapidly returning to normal atmospheric pressure. The air bubbles embolised his lungs. It is wrong to talk of "strain on elasticity of lungs" and of "ribs bearing the bulk" of the pressure, because the air pressure is equally distributed throughout the body.-I am, Sirs. jours faithfully,

Loughton, Dec. 14th, 1905 